\title{
Application of a Three-Segment E-learning Mode in Diagnostics Course Based on Rain Classroom
}

\author{
Si-min Huang ${ }^{1}$, Jing Yang ${ }^{1}$, Chun-ting $\mathrm{Lu}^{2}$, Peng Xu ${ }^{3}$, Jun Guo ${ }^{1} \&$ Sheng-ming Liu ${ }^{1}$ \\ ${ }^{1}$ Department of Internal Medicine, The First Affiliated Hospital of Jinan University, Guangzhou, China \\ ${ }^{2}$ The Science \& Education Office, The First Affiliated Hospital of Jinan University, Guangzhou, China \\ ${ }^{3}$ Department of Emergency, The First Affiliated Hospital of Jinan University, Guangzhou, China
}

Correspondence: Jun Guo \& Sheng-ming Liu, Department of Internal Medicine, The First Affiliated Hospital of Jinan University, Guangzhou 510630, Guangdong, China.

Received: May 17, 2020

doi:10.5430/irhe.v5n2p16
Accepted: June 6, 2020

Online Published: June 28, 2020

URL: https://doi.org/10.5430/irhe.v5n2p16

This study was supported by educational technological "innovation program" of Jinan University (grant number: JNU-J-CXGC2018003); education reform projects of Jinan University (grant number: JG2018037; JG2018054; JG2019013; JG2019044; JG2019127).

\begin{abstract}
Changes in the educational situation and characteristics of students are posing challenges to modern education. Exploring teaching modes suitable for today's college students become an important topic. In this study, a new teaching mode of three-segment (pre-, in- and post-class) based on the Rain Classroom e-learning platform was introduced into the processes of teaching Diagnostics Course for students in grade 2015 majoring in clinical medicine. The research were conducted by three-segment including that the teacher shared the pre-class learning materials with students before class, while real-time communication and timely feedback on teaching efficiency in class, and at last homework assignments were shared and still tracked the students' learning after class. The results of the new teaching mode were assessed mainly through the whole teaching and learning performance, final examinations and questionnaires as well. Compared with students in grade 2014 clinical medicine major who were adopted the traditional teaching mode, students in grade 2015 had a significantly higher pass-rate, and the percentage of high-score on the final exam was also higher. In questionnaires, students in grade 2015 generally recognized that the new teaching mode was conducive to improving learning outcomes. In conclusion, the investigation and application of the Rain Classroom platform-based new teaching mode of Diagnostics was a successful trial. This new teaching mode can significantly improve teacher-student interaction; help teachers track students' learning outcomes throughout the teaching process and effectively regulate the teaching strategies. Fundamentally, it can improve students' learning interest, promote active learning and enhance academic performance among students.
\end{abstract}

Keywords: e-learning, rain classroom, teaching mode, medical education

\section{Introduction}

With the rapid development of the Internet and information technology, the past 30 years have witnessed tremendous changes in all areas of society. In the 1980s, digital technology began to be integrated into social life (Jones, Ramanau, Cross, \& Healing, 2010). The impact of technological advances on modern civilization is reflected in all aspects of society, including education (Jamie, Tyler, \& Patricia, 2015). In the $21^{\text {st }}$ century, e-learning based on the Internet and information technology has been increasingly adopted in the field of education (Baker \& Yacef, 2009; Cela, Sicilia, \& Sanchez, 2015; Chen, Chen, \& Tsai, 2009; Chen \& Liu, 2017; Rodrigues, Almeida, Figueiredo, \& Lopes, 2019), especially in higher education, leading to major changes in how students learn and communicate (Rodrigues et al., 2019). Application of e-learning in higher education is a very important issue (Arkorful \& Abaidoo, 2014). Successful e-learning projects, conducted in many fields, including medicine, have attracted widespread attention (Chen et al., 2009).

The application of the Internet and information technology has provided technical support for the development of e-learning. Using these technologies to improve the quality of education and find a teaching mode suitable for 
modern college students have become important topics. Most college students nowadays are so-called "digital natives" (Jones et al., 2010; Yan \& Li, 2017), which refers not to the youth of a certain country but to that of the entire world (Rosenfeld, 2010). Compared with the older generation, these young people, who have grown up with computers and the Internet, are more adept with new technologies (Jones et al., 2010). Therefore, developing effective teaching methods for these digital natives have become a real challenge for teachers (Lim, Zhao, Tondeur, Chai, \& Tsai, 2013). As the traditional teacher-centered teaching mode no longer meets the needs of the new educational environment, schools and teachers must make changes. The focuses of teaching must gradually shift to "student-oriented" and "capable of stimulating students' learning interest" and "improve students' learning motivation". At the same time, emphasize evaluation of and feedback on students' learning process. Although universities implementing and promoting new teaching modes such as e-learning face many challenges and must change to accommodate the changing times (Rodrigues et al., 2019), changing the teaching concept and developing a teaching mode suitable for modern college students are challenges in the new era that must be faced by modern teachers (Tang \& Wang, 2018).

Various e-learning modes based on the Internet and information technology (e.g., massive open online courses and flipped classrooms) are the best examples of changes in teaching modes and ideas. These modes make full use of the convenience of the Internet and combine online self-learning and classroom learning to provide students with a personalized learning environment, thereby enhancing teachers' teaching effectiveness and students' learning motivation. In China, e-learning platforms supported by the Internet and information technology have been booming, and many excellent teaching platforms, such as Weizhujiao, Rain Classroom, Ketangpai and Xuexixing, have been launched and widely used in universities (Xie, et al. 2019). The state has also strongly encouraged application of information technology in education. In April 2018, the Ministry of Education of the People's Republic of China issued the "Action Plan of Educational Informationization 2.0," which makes it clear that by 2022, teaching applications should cover all teachers, learning applications should cover all school-age students, and digital campus construction should cover all schools, to establish a grand platform of "Internet + education" that strives to build a new model for talent training under "Internet +" conditions. It is foreseeable that in the next few years, increasing numbers of applications and studies on the Internet and information technology will emerge in the field of education in China.

In this study, we wanted to investigate how to use online teaching platforms in the context of e-learning to change the traditional one-way direction of knowledge dissemination by teachers, pay more attention to teacher-student interaction, enhance students' learning enthusiasm and motivation, strengthen teachers' tracking of and feedback on students' learning process and evaluate the impact of the new teaching mode on teaching processes and outcomes. We chose Rain Classroom, an e-learning platform that has been jointly launched by Tsinghua University and XuetangX and widely used in teaching activities of various disciplines in universities since its introduction in April 2016 (Tang \& Wang, 2018; Liu, 2018; Chen \& Hu, 2018; Hu, Yang, \& Zhao, 2017; Hu, Hao, Zhou, \& Huang, 2017; Wang, 2018; Gu \& Ren, 2018; Li \& Song, 2018). Rain Classroom is a teaching software developed based on PowerPoint (PPT) and WeChat, mainly for higher education. The software has three components - mobile phone, desktop computer and remote server - with powerful functions including: 1) enabling teachers to share learning resources, such as massive open online courses (MOOCs), videos, audios, courseware and other materials, with students outside of class; 2) allowing real-time communication and feedback between teachers and students in class; and 3) automatically recording and collecting data on all teaching activities, allowing tracking, monitoring and real-time evaluation of the entire teaching process (Wang, 2017). Therefore, Rain Classroom can help teachers manage all aspects of a course, including developing teaching programs, adjusting teaching schedules and monitoring students' grasp of knowledge in real time. It effectively gives teachers and students new mode to share pre-, in- and post-class teaching links.

The main aim of this study was to explore a new teaching mode that integrated online and offline in pre-, in- and post-class three-segment of Diagnostics Course, and analyzed teaching and learning efficiency, and the students' perspectives on their user experience with Rain Classroom platform as well.

\section{Methods}

\subsection{Participants}

The subjects of this study were students in grade 2015 majoring in clinical medicine (six-year program) at Jinan University who took Diagnostics in the 2018-2019 academic year. These students were mainly from Hong Kong and Macau but also from Taiwan and Japan. 


\subsection{Course Schedule}

The course was taught from September 2018 to January 2019. Diagnostics is a bridge course of basic medicine and clinical medicine and an important basic clinical course. After completing basic courses such as anatomy, pathology and pathophysiology in their first and second years, students began to take clinical courses. The contents of Diagnosis included history taking, symptomatology, physical examination, punctures (thoracentesis, abdominocentesis, bone marrow puncture and lumbar puncture), electrocardiogram (ECG), laboratory diagnosis, disease diagnosis procedures, clinical thinking and medical records writing, etc., each containing theory and practice portions. The theory portion was taught in class by teachers from internal medicine and department of clinical laboratory. The practice portion, including skills teaching in the comprehensive clinical skills training center, hospital bedside teaching, etc., was taught in small groups by specialist teachers and full-time teachers. The teaching hour ratio for the theory and practice teaching portions was 1:1 (90:90), with theory taught three times a week (2 hours per session) and practice 1-2 times a week (4 hours per session). The textbook was "Diagnostics" (the $9^{\text {th }}$ version) for the major of clinical medicine, which is the "The $13^{\text {th }}$ Five-year Plan" textbook of the National Health Commission, published by the People's Medical Publishing House, and the "Learning and Practice Manual for the 'Diagnostics' Course," compiled by the First Clinical Medical College of Jinan University to further elaborate teaching goals, content and requirements in detail.

\subsection{Teaching Process}

\subsubsection{Installing Rain Classroom}

\subsubsection{Teacher Terminal}

This included PC and mobile phone terminals. The teacher downloaded and installed the Rain Classroom software on the computer, and the PPT interface after installation is shown in Figure 1. When creating a PPT, teachers could include online videos, quizzes, and exercises from various sources, such as MOOCs. When using Rain Classroom, the teacher logged on to its web version, set up the course curriculum and the class (Figure 2) and then invited students to join the class.

Mobile WeChat clients joined the Rain Classroom public account. The functions of the mobile terminal were identical to those of the computer website end except that in the class, the mobile phone could be used as a remote control, allowing random calls, send bonuses, checking answers to questions, etc.

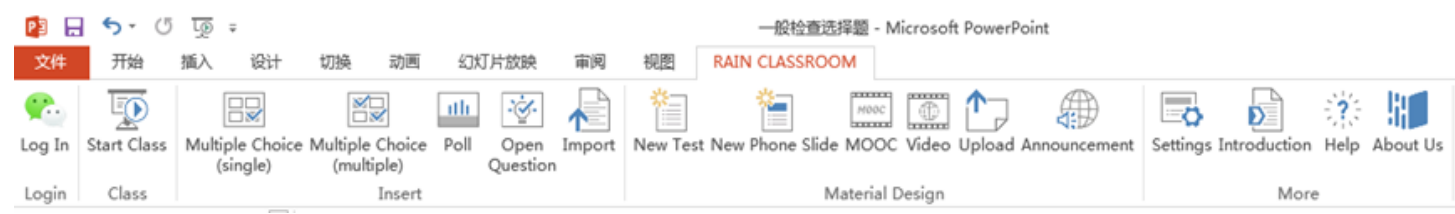

Figure 1. PPT interface after installing the Rain Classroom software

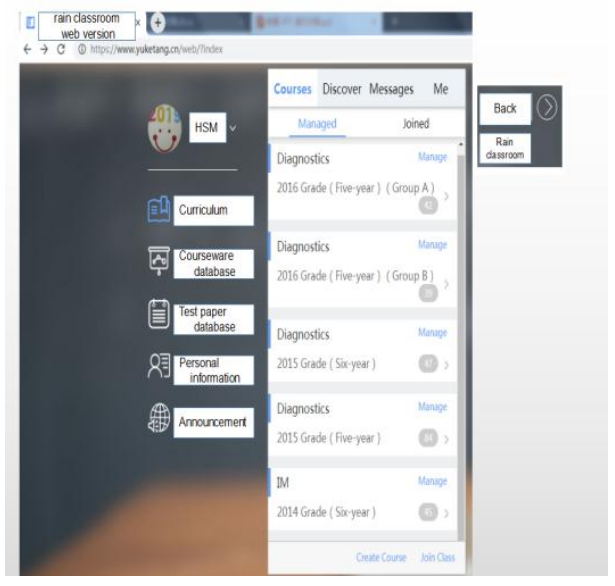

Figure 2. Rain Classroom webpage interface 


\subsubsection{Student Terminal}

The students joined the class by scanning or entering the invite code sent by the teacher (Figure 3), as they were able to receive and view messages posted by the teacher. Students could also log in to the Rain Classroom webpage to download and save materials.

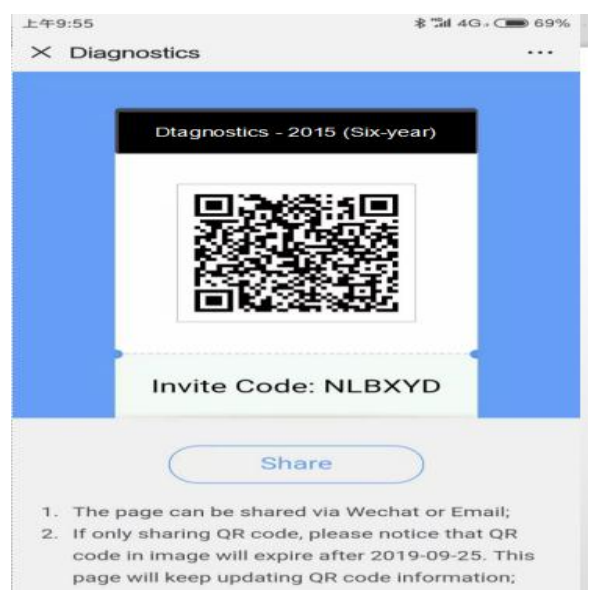

Figure 3. Invitation code for students to join the class

\subsubsection{Before Class}

Teaching objectives were set according to the syllabus. Before each practice class, the teacher shared the pre-class learning materials with students (Figure 4), the content of which was mainly important points of the lesson, mostly in the form of questions. For example, the pre-class learning materials on interviewing a patient with fever in the ward covered causes of fever, important points of fever for history taking and doctor-patient communication skills. The pre-class learning materials on physical examinations addressed the concept of physical examination, the concept of sign and the basic method of physical examination. At this stage, the teacher needed to track students' pre-class studying and collected feedback questions.

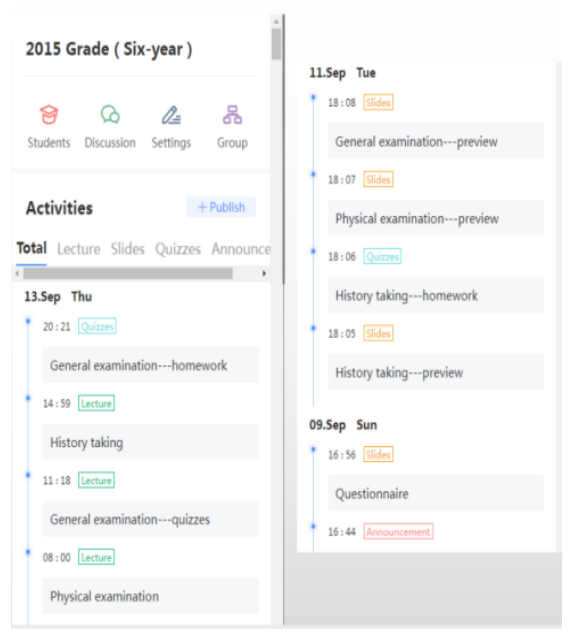

Figure 4. Teachers share pre-class learning materials through the platform

\subsubsection{During Class}

It included the following steps. 
1) Students scanned the code to enter the classroom. Students who were late could enter with "Class code" (Figure 5).

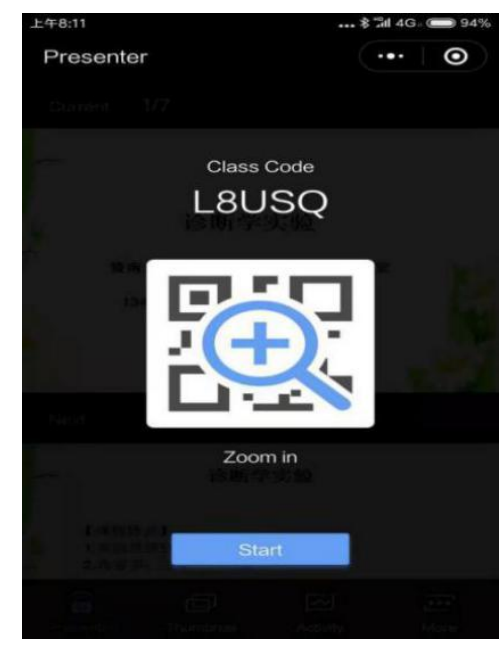

Figure 5. Classroom class code

2) When beginning teaching, the teacher sent the PPT page by page to students, who studied it and took notes through the mobile terminal.

3) Students could mark the PPT and send feedback by pressing the "do-not-understand" button on the points they had difficulty understanding, based on which the teacher promptly adjusted the teaching strategy and focused on teaching these particular knowledges.

4) The teacher turned on the "pop-up bubble" function to facilitate discussion and strengthen teacher-student and student-student interactions.

5) Students were called on to answer questions using the "roll call" function to assess students' learning outcomes (Figure 6).

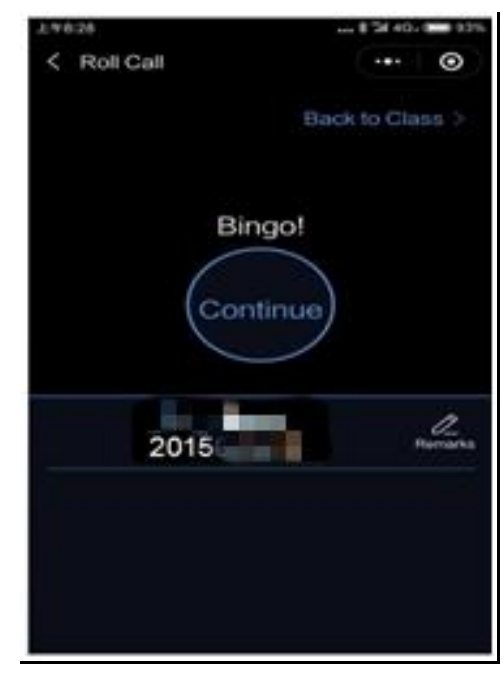

Figure 6. Random roll call

6) The teacher conducted in-class tests (Figure 7). Generally, before the end of class, an in-class test of 3-7 multiple-choice questions was conducted, the primary content of which was the main knowledge of that day. Both the teacher and the students learned the test results in real time, based on which the teacher gave a targeted summary and determined the emphasis of the homework while strengthening tutoring and tracking of students who did not 
perform well on the test. Through the test, students could assess their learning effectiveness and identify their weak areas (Figure 8).

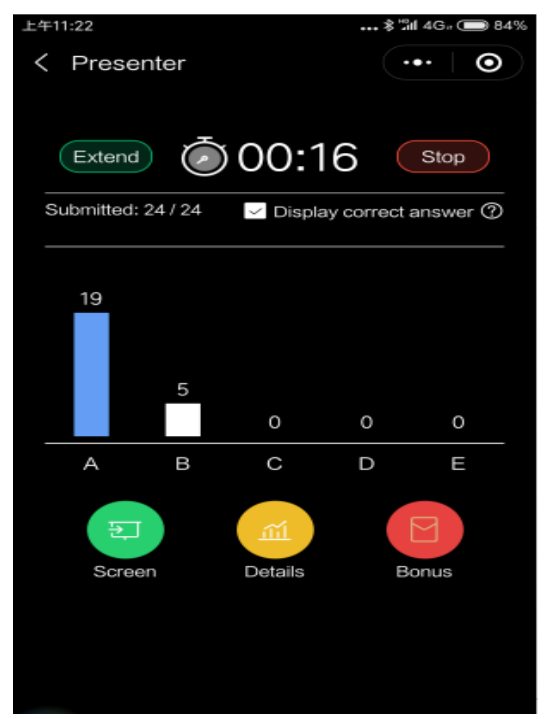

Figure 7. In-class test

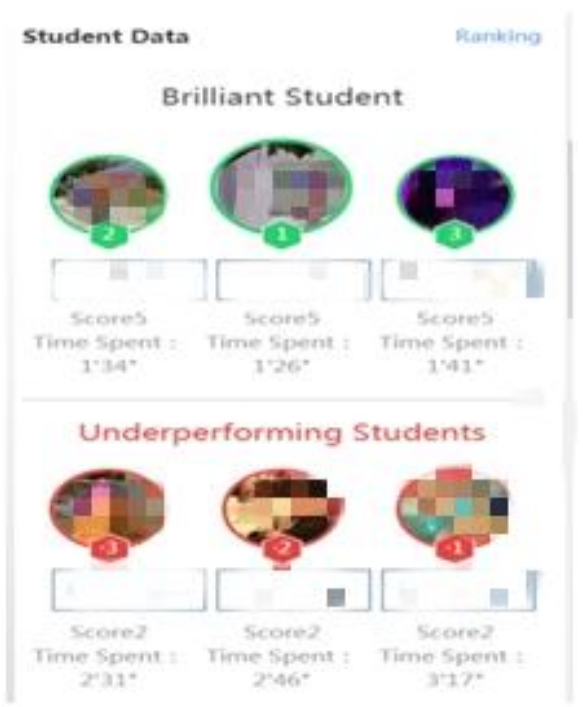

Figure 8. In-class test results

7) Students who performed well on the classroom test received a bonus (Figure 9).
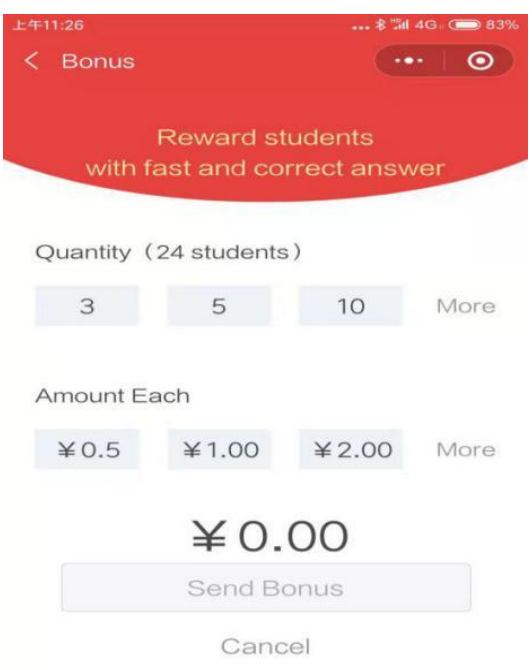

Figure 9. Bonus

8) Segment assessment

To assess the effect of the teaching in Weeks 1-9, an examination was conducted in Week 10, containing single-choice questions, cloze questions, concept explanations and short-answer questions, totally 100 points (Figure 10). In addition, examinations testing clinical skills were randomly performed in practice classes to evaluate students' mastery of clinical skills. Any problems with students' clinical skills were reflected and suggestions were given to students in the Rain Classroom platform in and after class. The classroom teaching scenes are shown in Figures $11-14$. 


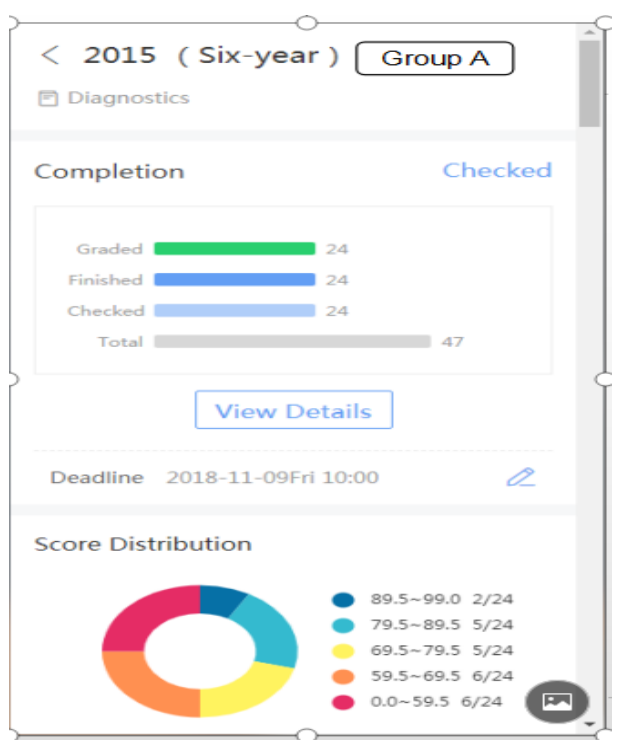

Figure 10. Segment test results

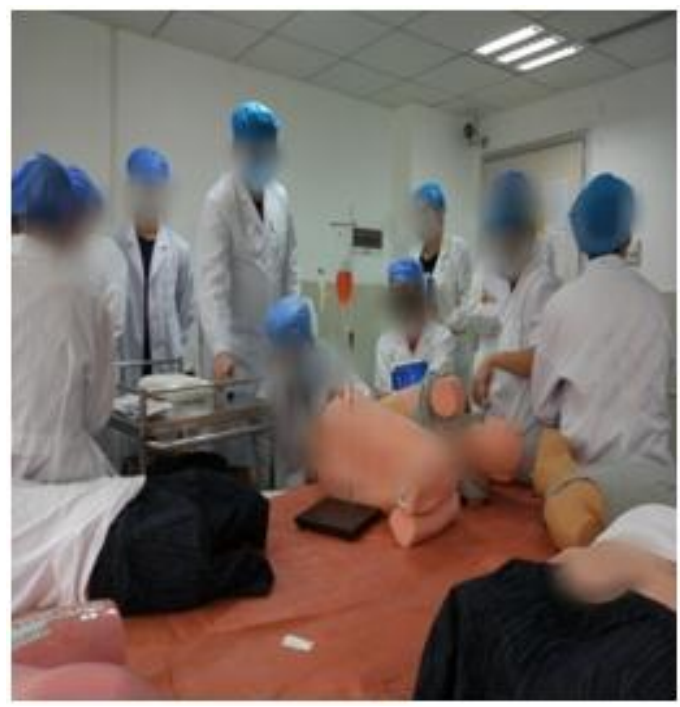

Figure 11. Classroom scene 1 (lumbar puncture)

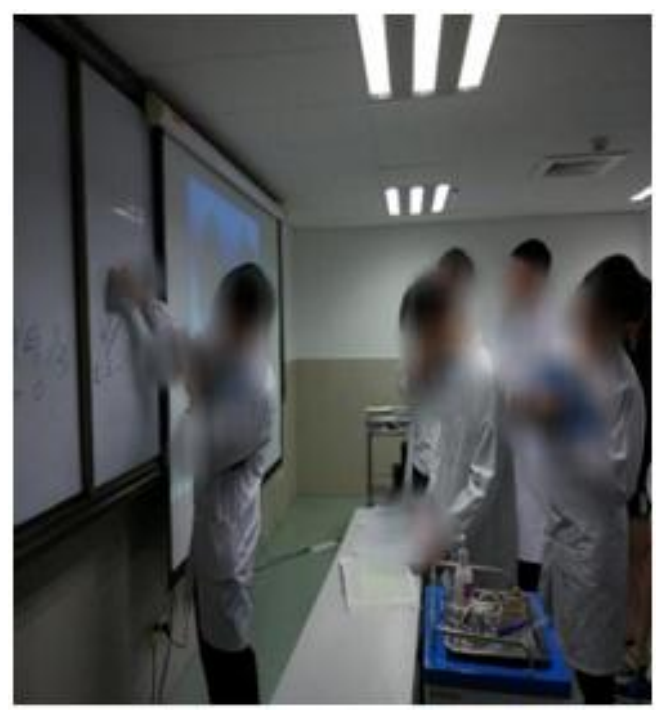

Figure 12. Classroom scene 2 (classroom discussion) 


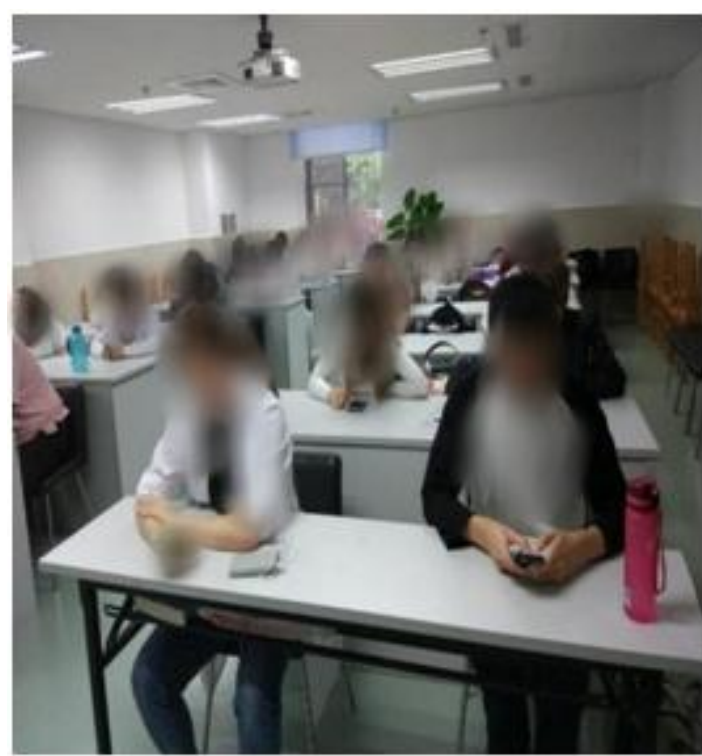

Figure 13. Classroom scene 3 (in-class test)

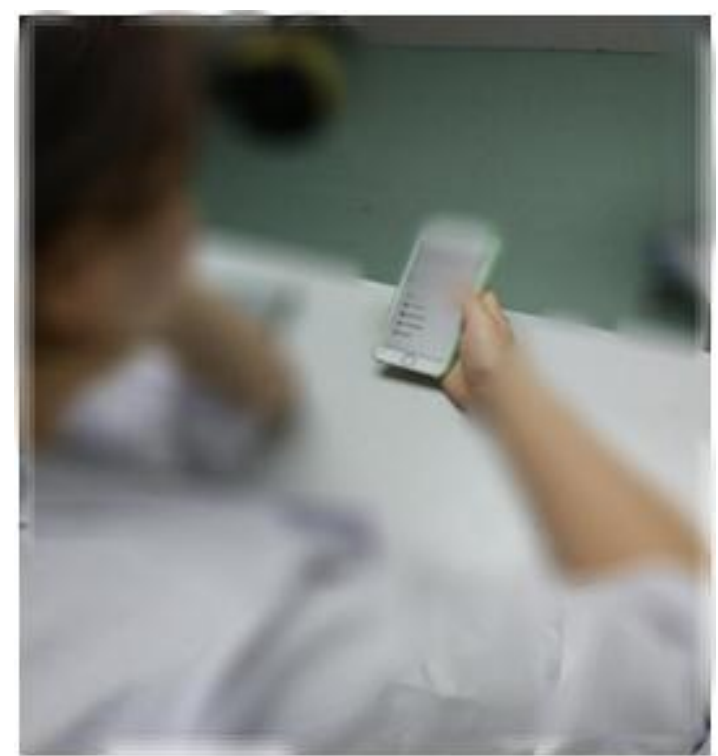

Figure 14. Classroom scene 4 (test with mobile phone)

\subsubsection{After Class}

Homework assignments, including definitions and concepts, single-choice questions and short-answer questions, were shared through Rain Classroom, and through one-on-one feedback, common problems were summarized and feedback. At the same time, the teaching plan was reviewed, and personalized tutoring was provided to individual students (Figure 15).

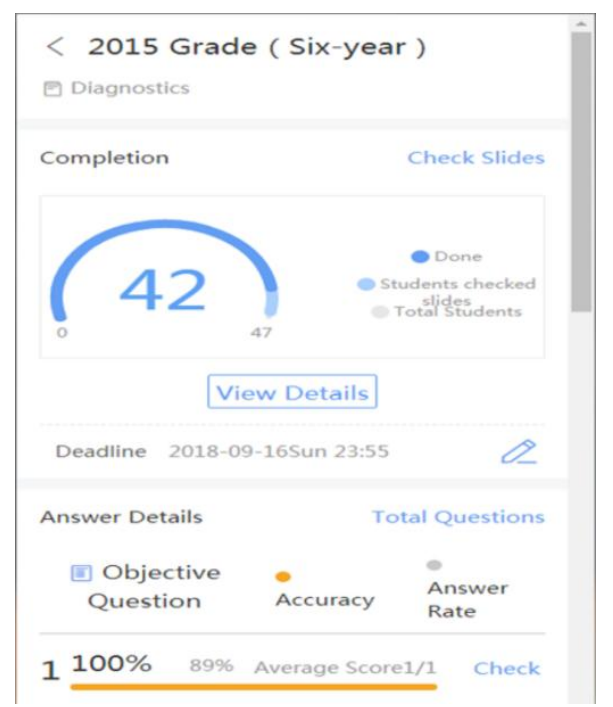

Figure 15. Homework assignment completion

The process and content of three-segment (pre-, in- and post-class) e-learning based on Rain Classroom are shown in Table 1. 
Table 1. Process and content of three-segment e-learning based on Rain Classroom

\begin{tabular}{|c|c|}
\hline Teaching process & Contents \\
\hline $\begin{array}{c}\text { Before } \\
\text { taking the course }\end{array}$ & $\begin{array}{l}\text { 1. Download and install the Rain Classroom software. } \\
\text { 2. Create course and class and invite students to join the group. } \\
\text { 3. Distribute questionnaire to learn about students' basic course learning, } \\
\text { learning habits and language issues, and information about issuance of } \\
\text { doctors' certificates in the students' places of origin to enable the teacher to } \\
\text { give personalized instruction. }\end{array}$ \\
\hline Before class & $\begin{array}{l}\text { 1. Design teaching goals and share pre-class learning materials. } \\
\text { 2. Follow up on students' study of the pre-class learning materials and collect } \\
\text { students' feedback. }\end{array}$ \\
\hline In class & $\begin{array}{l}\text { 1. Students scan the code to enter the classroom. } \\
\text { 2. The teacher sends the PPT page by page to students' WeChat terminals. } \\
\text { 3. Students answer questions through roll call. } \\
\text { 4. Open the "pop-up bubble" discussion function to discuss. } \\
\text { 5. For content that is not understood, a student can use the "do-not-understand" } \\
\text { button to provide immediate feedback to the teacher. } \\
\text { 6. Conduct in-class test with time limit to prompt students to concentrate on the } \\
\text { class. } \\
\text { 7. Send bonus to students to motivate them. } \\
\text { 8. Conduct segment examination to strengthen the evaluation of teaching } \\
\text { effectiveness. }\end{array}$ \\
\hline After class & $\begin{array}{l}\text { 1. Assign homework by sharing it through the platform. } \\
\text { 2. Correct homework and one-on-one feedback. Summarize common problems. } \\
\text { Review teaching plan and provide personalized tutoring for individual } \\
\text { students. }\end{array}$ \\
\hline
\end{tabular}

\subsection{Evaluation of Teaching Effectiveness}

Through formative assessments, final theory and clinical skills examinations and questionnaires, the outcomes of the new teaching mode were assessed.

\subsubsection{Formative Assessment via Rain Classroom}

Because Rain Classroom provides a platform for teacher-student interaction, records teaching activity data in real time and automatically generates statistics on test results and score distribution curves, the teacher could dynamically track the problems students encounter before, during and after class. The teacher could also routinely assess his or her teaching effectiveness, adjust his or her strategy to teach according to students' characteristics and implement more personalized and appropriate teaching.

\subsubsection{Final Exam}

Students' final grade was composed of two parts: a general score (accounting for 30\%) and a final exam score (accounting for $70 \%$ ). The former was based on class attendance, homework and classroom performance, and the latter is detailed in Table 2. The test scores of the students in grade 2015 were compared with those of the students in grade 2014 (six-year program) in the same major, who were also mostly from Hong Kong and Macau, as well as Taiwan and Japan. The contents, hours and teachers of the two classes were the same, as were the curriculum, homework and assessment standards. The students in grade 2014 were taught using the traditional teaching mode, i.e., mainly through face-to-face lecture by the teacher, in which students' learning outcomes were assessed through in-class work and post-class homework while in-class feedback was mainly directed to common problems. The segment examinations of the students in grade 2014 were conducted mainly in the traditional paper-testing format. 
Table 2. Examination contents of the three modules of diagnostics

\begin{tabular}{|c|c|}
\hline Modules and contents & Question type and scoring \\
\hline \multirow[t]{2}{*}{$\begin{array}{l}\text { Module 1: } \\
\text { Symptomology and } \\
\text { history taking }\end{array}$} & $\begin{array}{l}\text { Theory assessment: four concept questions ( } 2.5 \text { points/question; } \\
\text { total: } 10 \text { points); } 10 \text { cloze questions ( } 1 \text { point/question; total: } 10 \\
\text { points); } 50 \text { multiple-choice questions ( } 1 \text { point/question; total: } 50 \\
\text { points); six short-answer questions ( } 5 \text { points/question; total: } 30 \\
\text { points). The total possible score was } 100 \text { points. }\end{array}$ \\
\hline & History taking test. \\
\hline $\begin{array}{l}\text { Module 2: } \\
\text { Physical examination, } \\
\text { laboratory examinations, } \\
\text { clinical thinking and } \\
\text { diagnostic analysis }\end{array}$ & $\begin{array}{l}\text { Theory assessment: four concept questions ( } 2.5 \text { points/question; } \\
\text { total: } 10 \text { points); } 10 \text { cloze questions ( } 1 \text { point/question; total: } 10 \\
\text { points); } 50 \text { single-choice questions ( } 1 \text { point/question; total: } 50 \\
\text { points); six short-answer questions ( } 5 \text { points/question; total: } 30 \\
\text { points). The total possible score was } 100 \text { points. }\end{array}$ \\
\hline & This included three parts: \\
\hline Module 3: & $\begin{array}{l}\text { 1. Physical examination ( } 30 \%) \text { : complete physical examination with } \\
17 \text { assessment items, of which one was randomly chosen. }\end{array}$ \\
\hline $\begin{array}{l}\text { Skills test: physical } \\
\text { examination, punctures, } \\
\text { laboratory skills and }\end{array}$ & $\begin{array}{l}\text { 2. Punctures ( } 10 \%) \text { : in four assessment items (thoracentesis, } \\
\text { abdominocentesis, bone marrow puncture and lumbar puncture), of } \\
\text { which one was randomly chosen. }\end{array}$ \\
\hline ECG analysis & $\begin{array}{l}\text { 3. Laboratory skills and ECG analysis ( } 30 \%) \text { : experimental } \\
\text { operation ( } 9 \text { points); two short-answer questions ( } 3 \text { points/question; } \\
\text { total: } 6 \text { points). Identification of five peripheral blood cells or } \\
\text { structures via microscopy ( } 1.5 \text { points/cell or structure; total: } 7.5 \\
\text { points). Analysis of five ECGs ( } 1.5 \text { points/ECG; total: } 7.5 \text { points). }\end{array}$ \\
\hline
\end{tabular}

\subsubsection{Questionnaire Survey}

After the final exam, students in grade 2015 were given a questionnaire survey. The contents of the questionnaire are shown in Table 4.

\subsection{Statistical Method}

The data were analyzed using the SPSS 21.0 software. Quantitative data such as student test scores were expressed as mean \pm standard deviation, and qualitative data such as the distribution of score segments were expressed as number of cases and percentage. The two classes were compared using independent sample $t$-tests and chi-square analysis, in which a difference with a $P$ value lower than 0.05 was deemed statistically significant.

\section{Results}

\subsection{Basic Information on Students}

The number of students in grade 2014 was 39 (male: 20; female: 19), and that in grade 2015 was 47 (male: 28; female: 19).

\subsection{Comparison of Test Scores}

The scores of grade 2015 were significantly higher than those of grade 2014 in Modules 1 and $3(P=0.001)$. The score of grade 2015 was slightly higher than that of grade 2014 on Module 2, but the difference was not significantly different $(P=0.976)$. The statistics of the scores of the two classes are shown in Table 3 . 
Table 3. Comparison of test scores on the three modules between the two classes

\begin{tabular}{lccc}
\hline Contents & Grade 2014 $(\mathbf{n}=\mathbf{3 9})$ & Grade 2015 $(\mathbf{n}=\mathbf{4 7})$ & $\boldsymbol{P}$ \\
\hline Modules 1 & $68.64 \pm 8.64$ & $74.74 \pm 8.47$ & 0.001 \\
Modules 2 & $68.85 \pm 11.28$ & $69.91 \pm 9.45$ & 0.976 \\
Modules 3 & $74.61 \pm 8.84$ & $80.66 \pm 7.34$ & 0.001 \\
\hline
\end{tabular}

\subsection{Comparison of Score Segments Between Classes}

In addition to the total score, we also analyzed the distribution of the score segments on each module, and the results are as follows.

\subsubsection{Module 1}

The proportions of students scoring below 60 points were similar in the two classes (2.6\% vs. $2.1 \%$ ), but that of students scoring 70-79 points or above 80 points in grade 2015 was significantly higher than that of students in grade 2014, especially in the latter category (34\% vs. $12.8 \%)(P=0.019)$ (Figure 16).

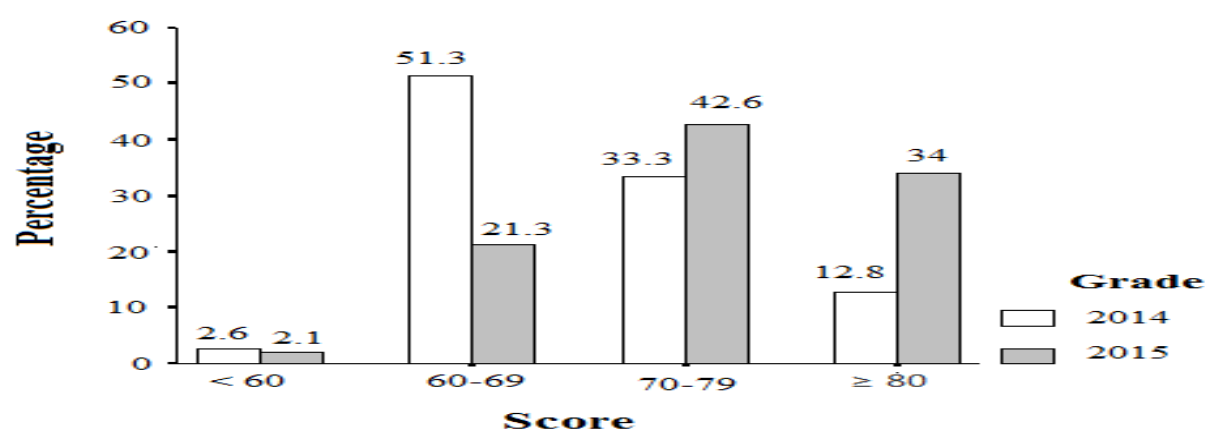

Figure 16. Comparison of score segments on Module 1 between the two classes

\subsubsection{Module 2}

Figure 17 shows that the proportion of students scoring below 60 points in grade 2015 was significantly lower than that of students in grade 2014 (8.5\% vs. 20.5\%), while that of students scoring 60-69 points or 70-79 points in Grade 2015 was significantly higher than that of students in grade 2014. However, the proportion of students scoring above 80 points in grade 2015 was lower than that of students in grade 2014 (12.8\% vs. $20.5 \%)$, with a statistically nonsignificant difference $(P=0.197)$.

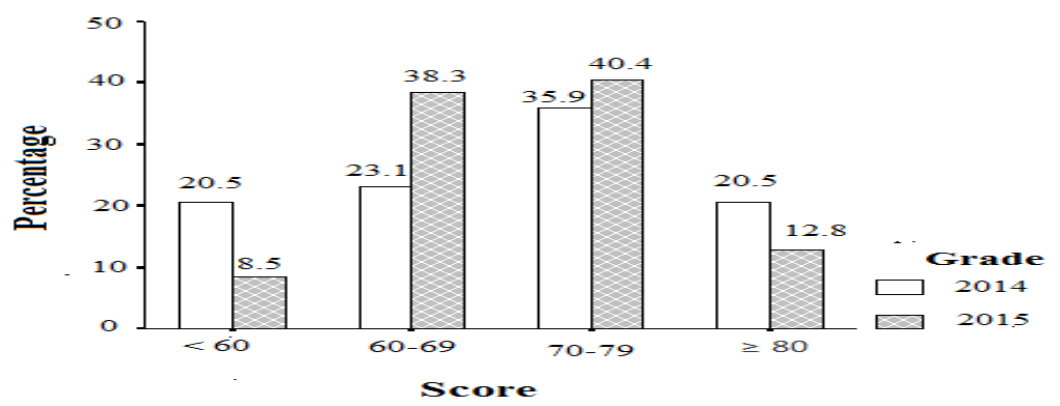

Figure 17. Comparison of score segments on Module 2 between the two classes

\subsubsection{Module 3}

The proportion of students scoring 60-69 points in grade 2015 was significantly lower than that of students in grade 2014 (8.5\% vs. $37.8 \%$ ), while that of students scoring $70-79$ points or $80-89$ points in grade 2015 was significantly 
higher than that of students in grade 2014. The proportion of students scoring 90 points or above in grade 2015 was $8.5 \%$, while none of the students in grade 2014. The differences between the two classes were statistically significant $(P=0.005)$ (Figure 18).

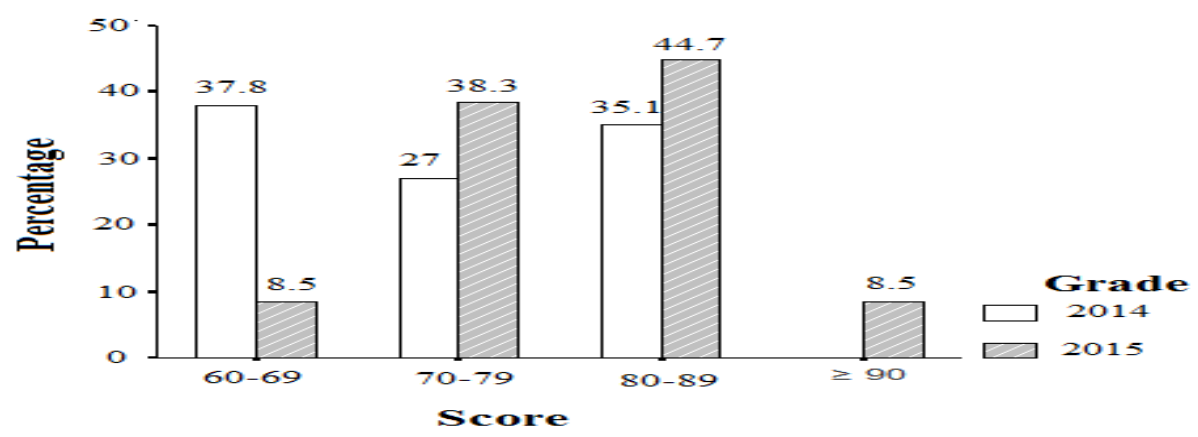

Figure 18. Comparison of score segments on Module 3 between the two classes

\subsection{Questionnaire Results}

After the final exam, a questionnaire survey was conducted through the Rain Classroom platform. Among 47 students in grade 2015, 44 completed the questionnaire, with a response rate of $93.62 \%$. Each item had five choices: Strongly agree (5 points), Agree (4 points), Neutral (3 points), Disagree (2 points) and Strongly Disagree (1 point). Details on and results of the questionnaire survey are shown in Table 4. The results show that students were satisfied with and recognized the value of the three-segment e-learning mode based on Rain Classroom. Among the items, in-class test and homework received very high evaluations.

Table 4. Questionnaire survey contents and results

\begin{tabular}{lc}
\hline \multicolumn{1}{c}{ Questionnaire contents } & Results \\
\hline $\begin{array}{l}\text { 1. Rain Classroom is an effective learning platform. } \\
\text { 2. Rain Classroom can strengthen communication and interaction between } \\
\text { teachers and students. }\end{array}$ & $3.77 \pm 0.74$ \\
$\begin{array}{l}\text { 3. Rain Classroom provides a freestyle learning method that can be conducted at } \\
\text { any time and place. }\end{array}$ & $4.43 \pm 0.82$ \\
$\begin{array}{l}\text { 4. Rain Classroom can save and record courseware, homework and other } \\
\text { materials, which can be downloaded at any time for review. }\end{array}$ & $4.14 \pm 1.05$ \\
$\begin{array}{l}\text { 5. The Rain Classroom-based teaching mode can improve students' learning } \\
\text { motivation. }\end{array}$ & $3.52 \pm 0.93$ \\
$\begin{array}{l}\text { 6. From the pre-class learning materials shared via Rain Classroom, I know } \\
\text { exactly what tasks to complete. }\end{array}$ & $3.95 \pm 0.10$ \\
7. In-class tests can assess the effectiveness of students' learning and help \\
students identify their weak points. \\
$\begin{array}{l}\text { 8. Homework assigned after class can help students consolidate their theoretical } \\
\text { knowledge from the textbook. }\end{array}$ \\
$\begin{array}{l}\text { 9. Learning through Rain Classroom will not increase the learning burden. } \\
\text { 10. I am in favor of continuing to use Rain Classroom as a learning platform for } \\
\text { future. }\end{array}$ \\
\hline
\end{tabular}




\section{Discussion}

As early as 1987, American scholars Chickering et al. (1989) proposed seven principles for best practices in undergraduate education: 1) encourage contact between students and faculty; 2) develop reciprocity and cooperation among students; 3) encourage active learning; 4) provide prompt feedback; 5) emphasize time on task; 6) communicate high expectations; and 7) respect diverse talents and ways of learning. In this study, by using e-learning platform and a new teaching mode based on Rain Classroom, we succeeded in strengthening teacher-student interaction, encouraging active learning, giving timely feedback, completing learning tasks on time and respecting different learning styles, which are five aspects of the above-described seven principles. The results showed that the three-stage (pre-, in- and post-class) e-learning mode can track, evaluate and provide feedback on students' learning throughout the process and ultimately achieve the goal of improving students' learning enthusiasm and academic performance by strengthening teacher-student interaction, teachers' management of students' learning process and teaching according to students' conditions.

Teaching is an interactive process between teachers and students. Amid an ever-changing teaching environment, some scholars argued that teachers and educational institutions have a responsibility to make changes based on the characteristics of the new generation of learners (Jones et al., 2010) and gradually shift from the teacher-led and teacher-centered paradigm to a teacher-guided and student-centered one. The development of the Internet and information technology has provided the basis for the transformation of education modes. Through the rich resources and new communication model provided by modern technologies such as the Internet, we can build various platforms in the field of education to create a new open and interactive learning environment, in which students are central and can learn in a personalized manner while teachers can enhance the assessment and management of students' learning process (Rodrigues et al., 2019). Many studies have shown that e-learning has a positive effect on improving students' learning motivation and learning effectiveness. For example, in a study by Liaw et al. (2017), 171 students from a university in Taiwan attended the course "Introduction to Computer Science" or "Introduction to Computer Network". After the students learned through a digital platform for 6 weeks, the researchers conducted a questionnaire survey of the students that included items on user experience with computers, the Internet and e-learning. They found that compared with traditional courses, e-learning promoted students' learning motivation more effectively. Application of e-learning in medical education has also achieved good outcomes, showing a positive impact on students' acquisition of theoretical knowledge and clinical skills (Poulsen, Friesgaard, Seidenfaden, Paltved, \& Nikolajsen, 2019; Dash, 2019; Mccutcheon, Lohan, Traynor, \& Martin, 2015; Weiner, et al. 2014).

Teachers' teaching strategy, methods, organization form and contents are all influencing factors of teaching outcomes. Some scholars noted that teachers' choice of teaching strategy is affected by students' cognitive and learning styles (Cheng \& Chau, 2016; Ma, 2008). Before the Internet and information technology were applied to education, it was difficult for teachers to track the learning status and learning style of each student in a timely manner, especially when the number of students exceeds a certain size. In traditional face-to-face teaching mode, teachers often deepen their understanding of students through students' in-class performance, homework and more frequent tests. However, these methods are inefficient and time consuming, making it difficult to obtain an accurate understanding of the learning status of each student in the class, let alone provide personalized tutoring to students in need. These problems can be solved by e-learning relying on information technology. In this study, in a context in which e-learning is popular worldwide, we changed the traditional teaching mode by introducing e-learning platform into the classroom in Diagnostics. By using Rain Classroom platform, we were able to track students' learning through the three teaching segments (pre-, in- and post-class), strengthen evaluation and management in the teaching process and provide timely feedback on learning effectiveness, especially for students with learning difficulties, who were promptly assisted in a personalized manner. We adopted the final exam score as a main means of quantitative assessment for the new teaching mode and found that the grade that adopted the new teaching mode had a significantly higher pass rate than the grade that used the traditional teaching mode. The proportion of the students that earned high scores on the final exam was also higher. In a research conducted by $\mathrm{Hu}$ et al. (2017), the above-described three-segment e-learning (treatment group) was used in teaching students majoring in accounting, with the traditional teaching mode as the control group. At the beginning of instruction, the two groups showed no significant difference in students' test scores in a "Tax Law" course. However, the researchers found that students' final exam score in the treatment group was significantly higher than that of the control group after one semester of e-learning, and within the treatment group, the difference between test scores before and after adopting e-learning was also statistically significant. Therefore, they concluded that the three-segment e-learning mode based on Rain Classroom ensured effective teacher-student interaction, which improved not only the quality of teaching but also 
students' learning enthusiasm and motivation. This conclusion is consistent with the results of ours and previous studies (Tang \& Wang, 2018; Liu, 2018; Chen \& Hu, 2018).

To assess the effectiveness of a teaching mode based on e-learning platform, not only the students' final examination scores, but also their perspectives, evaluation and satisfaction were need to be concerned and analyzed as an important indicator of teaching quality. (Rodrigues et al., 2019). Researches indicated that student satisfaction was an important indicator of e-learning, which was positively correlated with students' academic performance (Kuo, Walker, Belland, \& Schroder, 2013; Kuo, Walker, Schroder, \& Belland, 2014; Kuo \& Belland, 2016). Teacher-student interaction and learning contents were significant predictors of student satisfaction (Kuo et al., 2013; Kuo et al., 2014; Kuo \& Belland, 2016). E-learning improves communication and interaction between teachers and students and between students and thus student satisfaction with the curriculum (Benta, Bologa, \& Dzitac, 2014). Kangas et al. (2017) found that student satisfaction ultimately depends on teachers' participation and teaching decisions, the new learning environment based on digital technology and active participation not only helped stimulate students' interest in learning but also increased their engagement in learning and satisfaction, ultimately improved their learning motivation. In teaching process, teachers should play a facilitator role and educators should learn how to use information technology to provide an active learning environment (Cercone, 2008). A three-year study of online teaching satisfaction with graduate and undergraduate students was reported, the authors found that active interaction between teachers and students is the determinant factor of e-learning satisfaction while the most unsatisfactory element for students is "lack of interaction." It is worth noting that they found that some partial online courses are more satisfactory than full online courses (Cole, Shelley, \& Swartz, 2014). Our findings demonstrate that the three-segment e-learning mode based on Rain Classroom helps strengthen teacher-student interaction, facilitates teachers' provision of personalized assistance to needy students and improves students' academic performance. Students also recognized the value of Rain Classroom platform and benefit from the new teaching mode.

In addition to teacher-student interaction, a lack of time and space constraints was another profound feature of e-learning (Liaw et al., 2007; Tsai, Chuang, Liang, \& Tsai, 2011). E-learning courses offered convenience and flexibility absent in traditional face-to-face classes (Gregory \& Lampley, 2016), through which students can study outside the classroom according to their actual situations. Previous research has shown that "convenience" is the most satisfying aspect for students of studying online (Cole et al., 2014). In this study, the new three-segment e-learning mode based on Rain Classroom platform extends the time and space of traditional teaching, so that "teaching" and "learning" are not necessarily performed at the same time and place. Students can download the learning materials at any time and place. The results of the questionnaire survey show that the convenience and flexibility of the Rain Classroom platform are highly regarded by students.

There are some limitations in this study. First, Diagnostics includes many clinical skills. In the teaching process, strengthening and assessing students' clinical and practical ability and establishing preliminary clinical thinking are important teaching contents. The practical portions of the course, such as history taking, physical examination and punctures, require students to practice repeatedly to improve. How this new teaching mode employing the Internet and information technology improves students' basic skills requires further investigation. While some scholars believe that the effectiveness of e-learning is no less than that of traditional methods, they also emphasize the need for research and evaluation of the effectiveness of hybrid learning methods in teaching and improving clinical skills (Mccutcheon et al., 2015; Vaona, et al. 2018). Our findings and those of other studies on e-teaching platforms using various Internet and information technology indicate that this change in teaching mode can have obvious benefits. In addition, the questionnaire in this study did not involve students' evaluation of the course contents. Learning contents could significantly affect student satisfaction when evaluating curricula, and as a result, teachers and curriculum designers should pay more attention to the design and organization of learning contents (Kuo et al., 2013; Kuo et al., 2014). Researches showed that student-centered curriculum design can stimulate students' enthusiasm for learning and that an appropriate curriculum can help improve student learning outcomes (Bhagat, $\mathrm{Wu}, \& \mathrm{Chang}$, 2016; Ren, Dai, Zhao, Fei, \& Gan, 2017). In future applications of this new teaching mode based on Rain Classroom, combining the characteristics of the course to explore will be considered, for example, expand sharing of teaching resources on the platform; create and promote various teaching materials such as videos, clinical case discussions; encourage students to upload practical videos. So, teachers and students can discuss the skills and difficulties of various contents, while making the course contents more attractive to students and thus further increasing their learning interest. 


\section{Conclusion}

In this study, three teaching-segment (pre-, in- and post-class) modes were used and provided personalized assistance to students through the Rain Classroom e-learning platform by means of the advantages of the Internet resources and convenience in order to strengthen the interaction between teachers and students. This method was greatly helpful for the teachers to track the whole process in three periods while for the students to have more flexible and effective plan in learning. The design that learning materials were shared before class could give students adequate time to prepare for the contents earlier, so that they had a good knowledge background to understand the instruction and let the teachers to control the lecture given well in the classroom. That was, more key-points and difficult parts or the most concerned questions by the students in their feedback during the pre-class learning process would be explained and discussed in the class. Besides, those unknown questions would be fulfilled by homework assignments or continued to discuss in rain classroom online. At the same time through each teaching segment, students were provided timely feedback, in-class quizzes and segmental tests. All these settings were considered particularly important to assess students' learning efficiency and let the teaching activities more targeted.

This new teaching mode enabled classroom teaching to achieve more satisfactory teaching goals while to allow students more opportunities to participate in learning at the cognitive level and to encourage their active learning. By this way, the teachers had been more focused on whether the students had understood and mastered the knowledge, and given more well-organized teaching activities based on pre-class implement and post-class learning results, and not like the traditional classroom which just kept the students in the classroom or monologues delivered. The research was conducted by three-segment modes in flexible application of online and offline platform in order to make internet education advantages predominant and overcome the shortages of traditional teaching methods. Furthermore, the new teaching mode had solved various problems such as students' poor learning motivation, low participation and insufficient personalized guidance etc.in traditional classroom.

In conclusion, the investigation and application of the Rain Classroom platform in Diagnostics course was a successful trial. This new teaching mode can significantly improve teacher-student interaction; can help teachers track students' learning outcomes throughout the teaching process and effectively regulate the teaching strategies. Fundamentally, it can improve students, learning interest, promote active learning and enhance academic performance among students.

\section{Acknowledgements}

The authors would like to thank all of the teachers from different specialties in internal medicine and department of clinical laboratory and the medical students who participated in this study.

\section{Competing interests}

The authors declare that they have no competing interests.

\section{Author contributions}

Si-min Huang and Jing Yang performed this study and were involved in the teaching process, conception, design, analysis, interpretation of the result and funding acquisition. Si-min Huang wrote the original draft. Jang Yang edited the draft. Chun-ting $\mathrm{Lu}$ and Peng $\mathrm{Xu}$ were responsible for software, collected and analyzed the data. Jun Guo and Sheng-ming Liu participated in the design of the study, project administration, and supervision, funding acquisition, reviewed and edited the paper. All authors read and approved the final manuscript.

\section{Ethics Approval and Consent to Participate}

The course Diagnostics in this study was a compulsory course for students. It was a new attempt and reform of teaching method. Our method was non-invasive and had no influence on students and patients. Therefore, ethical approval was not applied for.

Fuzzy processing was taken on the pictures involving in this paper in order to protect students' privacy, and obtained the consent of students.

\section{References}

Arkorful, V., \& Abaidoo, N. (2014). The role of e-learning, the advantages and disadvantages of its adoption in Higher Education. International Journal of Education and Research, 2(12), 397-410.

Baker, R. S. J. D., \& Yacef, K. (2009). The State of Educational Data Mining in 2009: A Review and Future Visions. Computer Communications, 6(2), 82-87.

Benta, D., Bologa, G., \& Dzitac, I. (2014). E-learning Platforms in Higher Education. Case Study. Procedia 
Computer Science, 31, 1170-1176. https://doi.org/10.1016/j.procs.2014.05.373

Bhagat, K. K., Wu, L. Y., \& Chang, C. Y. (2016). Development and Validation of the Perception of Students towards Online Learning. Educational Technology \& Society, 19(1), 350-359.

Cela, K. L., Sicilia, M. A., \& Sanchez, S. (2015). Social network analysis in e-learning environments: A preliminary systematic review. Educational Psychology Review, 27(1), 219-246. https://doi.org/10.1007/s10648-014-9276-0

Cercone, K. (2008). Characteristics of adult learners with implications for online learning design. Association for the Advancement of Computing in Education Journal, 16(2), 137-159.

Chen, J. P., \& Hu, J. (2018). Enhancing L2 Learners' Critical Thinking Skills through a Connectivism-Based Intelligent Learning System. International Journal of English Linguistics, 8(6), 12-21. https://doi.org/10.5539/ijel.v8n6p12

Chen, R. S., \& Liu, I. F. (2017). Using a two-stage system evaluation approach to explore the new adoption of an information system in the mobile era. Journal of Educational Computing Research, 55(7), 996-1021. https://doi.org/10.1177/0735633117692102

Chen, Y., Chen, N. S., \& Tsai, C. C. (2009). The use of online synchronous discussion for web-based professional development for teachers. Computers \& Education, 53(4), 1155-1166. https://doi.org/10.1016/j.compedu.2009.05.026

Cheng, G., \& Chau, J. (2016). Exploring the relationships between learning styles, online participation, learning achievement and course satisfaction: An empirical study of a blended learning course. British Journal of Educational Technology, 47(2), 257-278. https://doi.org/10.1111/bjet.12243

Chickering, A. W., \& Gamson, Z. F. (1989). Seven Principles for Good Practice in Undergraduate Education. Biochemical Education, 17(3), 140-141. https://doi.org/10.1016/0307-4412 (89)90094-0

Cole, M. T., Shelley, D. J., \& Swartz, L. B. (2014). Online instruction, e-learning, and student satisfaction: A three year study. International Review of Research in Open and Distance Learning, 15(6), 111-131.

Dash, S. (2019). Google Classroom as a Learning Management System to Teach Biochemistry in a Medical School. Biochemistry and Molecular Biology Education, 47(4), 404-407. https://doi.org/10.1002/bmb.21246

Gregory, C. B., \& Lampley, J. H. (2016). Community College Student Success in Online Versus Equivalent Face-to-Face Courses. Journal of Learning in Higher Education, 12(2), 63-72.

Gu, H. Y., \& Ren, L. (2018). Enhancing the Teaching Effect of ESP for Engineering Students with Interactive Tools Based on WeChat. IEEE Global Engineering Education Conference, 800-804.

Hu, Y., Hao, Q., Zhou, Y., \& Huang, Y. F. (2017). Interactive teaching and learning with smart phone app in Optoelectronic Instruments course. Society of Photo-Optical Instrumentation Engineers (SPIE) Conference Series, 10452:104521U-1-104521U-4. https://doi.org/10.1117/12.2269504

Hu, Z. R., Yang, Q. J., \& Zhao, X. G. (2017). Empirical Study on the Teaching Model of Autonomous Learning Course, Based on the "Rain Class" of Higher Vocational Students. International Conference on Modern Education and Information Technology (MEIT 2017), 42-47.

Jamie, L. J., Tyler, A. K., \& Patricia, D. D. M. G. (2015). Improvements from a Flipped Classroom May Simply Be the Fruits of Active Learning. CBE—Life Sciences Education, 14, 1-12. https://doi.org/10.1187/cbe.14-08-0129

Jones, C., Ramanau, R., Cross, S., \& Healing, G. (2010). Net generation or Digital Natives: Is there a distinct new generation entering university?. Computers \& Education, 54(3), 722-732. https://doi.org/10.1016/j.compedu.2009.09.022

Kangas, M., Siklander, P., Randolph, J., \& Ruokamo, H. (2017). Teachers' engagement and students' satisfaction with a playful learning environment. Teaching and Teacher Education, 63, 274-284. https://doi.org/10.1016/j.tate.2016.12.018

Kuo, Y. C., \& Belland, B. R. (2016). An exploratory study of adult learners' perceptions of online learning: Minority students in continuing education. Educational Technology Research and Development, 64(4), 661-680. https://doi.org/10.1007/s11423-016-9442-9

Kuo, Y. C., Walker, A. E., Belland, B. R., \& Schroder, K. E. (2013). A predictive study of student satisfaction in online education programs. International Review of Research in Open and Distance Learning, 14(1), 16-39. https://doi.org/10.19173/irrodl.v14i1.1338 
Kuo, Y. C., Walker, A. E., Schroder, K. E., \& Belland, B. R. (2014). Interaction, Internet self-efficacy, and self-regulated learning as predictors of student satisfaction in online education courses. The Internet and Higher Education, 20, 35-50. https://doi.org/10.1016/j.iheduc.2013.10.001

Li, X. M., \& Song, S. Q. (2018). Mobile technology affordance and its social implications: A case of "Rain Classroom". British Journal of Educational Technology, 49(2), 276-291. https://doi.org/10.1111/bjet.12586

Liaw, S. S., Huang, H. M., \& Chen, G. D. (2007). An activity-theoretical approach to investigate learners' factors toward e-learning systems. Computers in Human Behavior, 23(4), 1906-1920. https://doi.org/10.1016/j.chb.2006.02.002

Lim, C. P., Zhao, Y., Tondeur, J., Chai, C. S., \& Tsai, C. C. (2013). Bridging the gap: Technology trends and use of technology in schools. Educational Technology \& Society, 16(2), 59-68.

Liu, W. W. (2018). College English Flipped Classroom in Applied Undergraduate Colleges Based on Rain Classroom. 2018 4th International Conference on Education, Management and Information Technology (ICEMIT 2018), 1223-1228.

Ma, Y. J. (2008). On Cognitive Style and Selection of Teaching Strategies. Journal of Weinan Teachers University, 23(3), 62-64 (in Chinese).

Mccutcheon, K., Lohan, M., Traynor, M., \& Martin, D. (2015). A systematic review evaluating the impact of online or blended learning vs. face-to-face learning of clinical skills in undergraduate nurse education. Journal of Advanced Nursing, 71(2), 255-270. https://doi.org/10.1111/jan.12509

Poulsen, M., Friesgaard, K. D., Seidenfaden, S., Paltved, C., \& Nikolajsen, L. (2019). Educational interventions to improve medical students' knowledge of acute pain management: a randomized study. Scandinavian Journal of Pain, 19(3), 619-622. https://doi.org/10.1515/sjpain-2019-0036

Ren, Y., Dai, Z. X., Zhao, X. H., Fei, M. M., \& Gan, W. T. (2017). Exploring an on-line course applicability assessment to assist learners in course selection and learning effectiveness improving in e-learning. Learning and Individual Differences, 60, 56-62. https://doi.org/10.1016/j.lindif.2017.09.002

Rodrigues, H., Almeida, F., Figueiredo, V., \& Lopes, S. L. (2019). Tracking e-learning through published papers: A systematic review. Computers \& Education, 136, 87-98. https://doi.org/10.1016/j.compedu.2019.03.007

Rosenfeld, J. (2010). Grown up digital: how the net generation is changing your world. Symbolic Interaction, 33(4), 640-643. https://doi.org/10.1525/si.2010.33.4.640

Tang, P. R., \& Wang, L. (2018). The Construction and Practice of the Flip Classroom in the Background of Rain Classroom. 2018 Northeast Asia International Symposium on Linguistics, Literature and Teaching (NALLTS), 529-532.

Tsai, C. C., Chuang, S. C., Liang, J. C., \& Tsai, M. J. (2011). Self-efficacy in Internet based learning environments: A literature review. Educational Technology \& Society, 14(4), 222-240.

Vaona, A., Banzi, R., Kwag, K. H., Rigon, G., Cereda, D., Pecoraro, V., et al.. (2018). E-learning for health professionals. Cochrane Database Systematic Reviews, 1. https://doi.org/10.1002/14651858.CD011736

Wang, J. J. (2018). Research on Blended Teaching Mode of College English based on Rain Classroom. Advances in Social Science, Education and Humanities Research, 294, 386-390.

Wang, S. G. (2017). Rain Classroom facilitating commencing the era of smart teaching. Modern Educational Technology, 27, 26-32 (in Chinese).

Weiner, D. K., Morone, N. E., Spallek, H., Karp, J. F., Schneider. M., Washburn. C., et al.. (2014). E-Learning Module on Chronic Low Back Pain in Older Adults: Evidence of Effect on Medical Student Objective Structured Clinical Examination Performance. Journal of the American Geriatrics Society, 62(6), 1161-1167. https://doi.org/10.1111/jgs.12871

Xie, H., Zhan, Y. H., Chen, D., Zeng, Q., Chen, X. L., Shen, X. M., et al.. (2019). The research of refinement and individuation in Microbiology Experiment teaching reform based on micro platform of online teaching. Microbiology China, 46(1), 192-202 (in Chinese). Retrieved from http://www.cnki.net/kcms/doi/10.13344/j.microbiol.china.180377.html

Yan, L. J., \& Li, Q. (2017). Design of Blended Learning Mode Based on WeChat Public Platform. International Conference on Education Innovation and Social Science (ICEISS 2017), 157, 229-232. https://doi.org/10.2991/iceiss-17.2017.55 